\title{
Altitudinal Distribution of Papilionidae Butterflies along with Their Larval Food Plants in the East Himalayan Landscape of West Bengal, India
}

\author{
Narayan Ghorai, Panchali Sengupta \\ Department of Zoology, West Bengal State University, Barasat, Kolkata, West Bengal, India \\ Email: nghorai@gmail.com, panchali_17sg@yahoo.com
}

Received October 2013

\begin{abstract}
The altitudinal distribution of Papilionidae butterflies across the East Himalayan Landscape of West Bengal, India is presented here. 26 butterfly species are known to occur across 11 altitudinal belts. Species Richness (R) and Species Diversity $\left(H^{\prime}\right)$ are said to be highest between 1200 - 1400 masl (meters above sea level). In contrast, lowest values of Species Richness and Species Diversity occur at the highest altitude of $\mathbf{3 0 0 0}$ masl and above. Maximum number of individuals occurs between 900 - 1100 masl while the minimum number of individuals was present at the highest altitude of 3000 masl or above. 35 species of plants belonging to 6 families served as the larval food plant of these butterflies. Thus the presence of suitable larval host plants probably governs the altitudinal distribution of these papilionid species of butterflies. $30.77 \%$ of butterfly species are strictly monophagous in nature.
\end{abstract}

\section{Keywords}

Altitudinal Distribution; Papilionidae; Himalayan Landscape; Species Richness; Species Diversity; Larval Food Plant

\section{Introduction}

The Himalayan range forms an arc between north-west to south-east, across the northern boundary of the Indian subcontinent. Here, Himalayas mainly refers to the region from Kashmir to Arunachal Pradesh, within Indian political boundaries. Also included in this range are northern Pakistan, northern Myanmar and the Himalayan kingdom of Nepal and Bhutan [1].

The Himalayan range with profoundly different climate and vegetation supports a diverse flora as compared to the rest of India. The vegetation pattern in the Himalayas predominantly varies from tropical-subtropical in the lower foothills and in warmer valleys to the temperate type which extends up to the higher altitudes. These peculiarities in the geographic, climatic and vegetation condition probably support the distinct butterfly fauna in 
this region. The Eastern Himalayas is more tropical with butterflies sharing affinities with that of the Oriental region. This region represents the transition zone between Indian, Indo-Malayan and Indo-Chinese biogeographic regions. However, butterflies inhabiting 3000 masl or above possess Palaerctic affinities [2].

A comparative account on the altitudinal distribution of Papilionid in the Eastern and Western Himalayas along with a note on their food plants has been presented [1]. A clear gradation in the species composition, richness and diversity of butterflies along altitudinal gradients is evident in the Western Himalayas [3]. This is supportive of the fact that a strong positive correlation exists between the altitudinal belts inhabited by the Papilionid butterflies and their larval food plants in the Western Himalayas [1]. The tropical and sub-tropical forest types of eastern Siwalik with diversified vegetation coupled with different climatic factors provides a preferable habitat for a diverse species of butterflies [4]. The lowland forests of the Himalayan kingdom of Bhutan harbors a rich and unique diversity of butterflies with a maximum number of species during spring season in contrast to a minimum number during monsoons [5].

Although a list of butterflies from the Darjeeling and Jalpaiguri district of West Bengal $[6,7]$ are available, however studies on the influence of altitudinal gradient on the distribution of butterflies in the East Himalayan landscape of West Bengal, India are lacking. Being a part of the East Himalayan-Indo-Burma hotspot, this "Papilionid-rich zone" has been a part of Swallowtail Conservation Action Plan by IUCN [8]. Since, the diversity of butterflies probably reflects the phenophase of their food plants [9], an attempt was also made to record the larval food plants of papilionid butterflies. Thus, the present study was designed keeping in mind the conservation value of this ecoregion, with respect to the Papilionidae butterflies.

\section{Methodology}

\subsection{Study Site}

The present study was conducted in the adjoining regions of the protected areas of Gorumara National Park (GNP) and Neora Valley National Park (NVNP). GNP $\left(26^{\circ} 42^{\prime} \mathrm{N}, 88^{\circ} 48^{\prime} \mathrm{E}\right)$ located in the Malbazar subdivision of the Jalpaiguri district of West Bengal, India belongs to biogeographical zone 7B [10]. It possesses Wet Mixed Forest (Wet Semi-evergreen forest), Tropical Moist Deciduous forests and savannah grasslands [11] which extends upto 180 masl. NVNP $\left(26^{\circ} 52^{\prime}-27^{\circ} 07^{\prime} \mathrm{N}, 88^{\circ} 45^{\prime}-88^{\circ} 55^{\prime} \mathrm{E}\right)$ is located in the Kalimpong subdivision of Darjeeling district of West Bengal, India. NVNP has wide altitudinal limits (183 - 3170 masl) with 3 zones of vegetation. Tropical lower hill forest, mostly deciduous and semi-evergreen, extends upto 750 masl. Sub-tropical middle hill forest is found over 750 - 1700 masl and temperate upper hill forests extend between 1700 - 3200 masl [12].

\subsection{Sampling Procedure}

11 altitudinal belts (upto 200 masl; 300 - 500 masl; 600 - 800 masl; 900 - 1100 masl; 1200 - 1400 masl; 1500 - 1700 masl; 1800 - 2000 masl; 2100 - 2300 masl; 2400 - 2600 masl; 2700 - 2900 masl and above 3000 masl) were identified in the study sites. Altitudes were noted from available toposheets (Geographical Survey of India). Monthly sampling of butterflies was conducted for a period between January-December 2012 with five days in each month. Pollard-walk method [13] was used for survey at three randomly selected line transects (approx. $500 \mathrm{~m}$ length and $8 \mathrm{~m}$ breadth) located in each of the altitudinal belts. The time allotted for checking each transect was 70 - 90 mins, which depended on the terrain. Each transect was checked daily between 9:00 - 11:30 hr and 13:30 - 15:30 hr.

\subsection{Identification of Butterflies and Their Larval Food Plants}

The butterflies were observed (using Bushnell binoculars) and photographed occasionally (using Nikon COOLPIX-P90) for subsequent identification from literature [2,14-17] and reference collection at Zoological Survey of India. Larval host plants were recorded in each transect and identified from published literature [18-21] along with assistance from the plant taxonomist.

\subsection{Data Analysis}

The diversity of butterfly species across different altitudinal belts was calculated using Shannon index of diver- 
sity given by the equation, $\mathrm{H}^{\prime}=\sum \mathrm{pi}(\mathrm{Inpi})$, where, $\mathrm{pi}=\mathrm{ni} / \mathrm{N}$; ni is the number of individuals of $i^{\text {th }}$ species and $\mathrm{N}=\sum$ ni. The Shannon index which combines the number of species within a site with the relative abundance of each species $[22,23]$ was determined using vegan package of " $R$ ". Margalef's species richness was used to compare the species richness across different altitudes. This index was calculated using equation $\mathrm{R}=(\mathrm{S}-1) / \mathrm{InN}$, where $\mathrm{S}$ is the number of species and $\mathrm{N}$ is the number of individuals [23]. The variation in butterfly species richness and species diversity across 11 altitudinal belts was represented graphically. Polyphagy indices of butterfly species was measured as $\mathrm{PI}=(\mathrm{A} \times \mathrm{B})^{1 / 2}$; where $\mathrm{A}=$ number of genera of host plants, and $\mathrm{B}$ $=$ taxonomic diversity of the hosts $(1=$ one plant species; $2=$ one plant genus; $3=$ one plant family; $4=$ one plant order; 5 = two or more plant orders) [24].

\section{Results}

The 26 species of Papilionid butterflies observed across 11 altitudinal belts throughout the entire study site is presented in Table 1. The values of Species Diversity $\left(\mathrm{H}^{\prime}\right)$ and Species Richness (R) of butterflies across different altitudinal belts are shown in Table 2. Accordingly, highest value of species diversity (2.999) and species richness (3.917) were observed between 1200 - 1400 masl. In contrast, lowest values of species diversity (0.974) and species richness (0.962) were recorded at highest altitudinal belt (above 3000 masl). Figure 1, representing the variation in butterfly species richness across 11 altitudinal belts showed a hump-shaped pattern in comparison to a species diversity curve which remained almost horizontal up to 2300 masl before declining sharply at higher altitudes. 35 species of plants belonging to 6 families serving as the larval food plants of these species of butterflies along with their polyphagy index values are also provided in Table 1. Graphium eurypylus larvae possessed highest polphagy index values of 4.472. 30.77\% of butterflies (Bhutanitis lidderdalei, Teinopalpus imperialis, Meandrusa payeni, Atrophaneura dasarada, Atrophaneura hector, Graphium nomius, Chilasa clytia and Troides helena), were strictly monophagous with a polyphagy index value of 1.000 indicative of their being host specialists.

\section{Conclusions}

Similar to other taxa, butterfly species richness depends on abiotic factors and varies with environmental gradients on continental mainlands [25-27]. These abiotic factors are probably known to influence the physiology of butterfly species and govern their distribution in different altitudinal belts across their study site. Lowest values of species richness observed at highest elevation is indicative of a negative correlation between species richness and their altitudinal distribution as evident amongst the butterflies from the Siwalik Himalayas [28]. [29] showed a hump-shaped pattern of the species richness curve up to a certain elevation before declining thereby confirming a similar pattern observed in our study.

Uniform variation in butterfly species diversity up to 2300 masl is probably associated with the availability of their food plants in suitable phenophases. In general butterfly species are found with the highest diversity in areas containing large amount of host plants [30] and butterfly diversity at local or regional scales is also closely related to their host plant density [31,32]. Such an intimate association between butterflies and their respective plants points towards the nature of vegetation being an important factor in determining the dependence and survival of a species in a particular habitat [33].

Complex ecological conditions produced as a result of interaction between butterflies and their host plants appears to be important aspect of biological diversification. Such interactions are predominantly governed by nutrient content [34], plant chemistry [35], phenology [36] and geographical distribution [37]. Greater diversity of vascular plants in tropical regions [38] could be an important precondition for increased herbivore insect diversity along lower altitudes. Host plant relationships of Papilionidae centres on a few families (Aristolochiaceae, Annonaceae, Lauraceae, Magnoliaceae and Rutaceae) and chemicals such as aristolochic acids, essential oils and certain alkaloids, have been identified as key mediators of host choice in papilionids from all major biogeographical regions [39]. Graphium species are low elevation butterflies that inhabit plains adjoining the hills and forest edges near human settlements [40] including two species (G. cloanthus and G. sarpedon) ascending upto 2750 masl [2]. [18] reported Uvaria macropoda and $U$. lurida from the lower Himalayan foothills of Northern Bengal. This probably supports the extensive distribution of Graphium antiphates during this study. Three species (Papilio polytes, P. demoleus and Chilasa clytia) are widespread along the Himalayan foothills. 
Table 1. List of papilionid butterfly species and their associated larval food plants in the study site along with their polyphagy index values.

\begin{tabular}{|c|c|c|c|c|}
\hline Sr.No & Common Name & Scientific Name & Larval food plants of butterflies & Polyphagy Index \\
\hline 1 & Bhutan Glory & $\begin{array}{l}\text { Bhutanitis lidderdalei } \\
\text { Atkinson }\end{array}$ & $\begin{array}{l}\text { Aristolochia griffithi Hook. f. \& Thoms. } \\
\text { Ex Duchartre in DC. (Aristolochiaceae) }\end{array}$ & 1.000 \\
\hline 2 & Kaiser-I-Hind & Teinopalpus imperialis Hope & Magnolia campbelli Hook. f. \& Thoms. (Magnoliaceae) & 1.000 \\
\hline 3 & $\begin{array}{l}\text { Glassy } \\
\text { Bluebottle }\end{array}$ & $\begin{array}{l}\text { Graphium cloanthus } \\
\text { Westwood }\end{array}$ & $\begin{array}{l}\text { Persea odoratissima (Nees) Kosterm (Lauraceae), } \\
\text { Michelia champaca Linn. (Magnoliaceae) }\end{array}$ & 3.1623 \\
\hline 4 & $\begin{array}{l}\text { Common } \\
\text { Bluebottle }\end{array}$ & $\begin{array}{l}\text { Graphium sarpedon } \\
\text { (Linnaeus) }\end{array}$ & $\begin{array}{l}\text { Polyalthia longifolia Hk. f. \& T. (Annonaceae), Persea odoratissima } \\
\text { (Nees) kosterm, Cinnamomum camphora (L.)J. Presl. (Lauraceae) }\end{array}$ & 3.873 \\
\hline 5 & Great Jay & $\begin{array}{l}\text { Graphium eurypylus } \\
\quad \text { (Linnaeus) }\end{array}$ & $\begin{array}{c}\text { Annona reticulata L, Polyalthia longifolia Hk. f. } \\
\text { \& T. (Annonaceae), Trachelospermum asiatica Nakai } \\
\text { (Apocyanaceae), Magnolia grandiflora L. (Magnoliaceae) }\end{array}$ & 4.472 \\
\hline 6 & Common Jay & $\begin{array}{l}\text { Graphium doson } \\
\text { (C. \& R. Felder) }\end{array}$ & $\begin{array}{l}\text { Polyalthia longifolia Hk. f. \& T. (Annonaceae), } \\
\text { Trachelospermum asiatica Nakai (Apocyanaceae), } \\
\text { Michelia champaca Linn. (Magnoliaceae) }\end{array}$ & 3.873 \\
\hline 7 & Tailed Jay & $\begin{array}{l}\text { Graphium agamemnon } \\
\text { (Linnaeus) }\end{array}$ & $\begin{array}{l}\text { Annona squamosa Linn., A.reticulata L, Artabotrys } \\
\text { hexapetalus (L.f) Bhandari, Polyalthia longifolia Hk. f. \& T. } \\
\text { (Annonaceae), Michelia champaca Linn., (Magnoliaceae) }\end{array}$ & 4.000 \\
\hline 8 & $\begin{array}{l}\text { Fivebar } \\
\text { Swordtail }\end{array}$ & Graphium antiphates (Cramer) & ) Uvaria macropoda Hk.f. \& T., U. lurida Hk.f. \& T. (Annonaceae) & 1.4142 \\
\hline 9 & Yellow Gorgon 1 & Meandrusa payeni (Boisduval) & Litsea citrata Blume. (Lauraceae) & 1.000 \\
\hline 10 & $\begin{array}{l}\text { Tawny } \\
\text { Mime }\end{array}$ & Chilasa agestor (Gray) & $\begin{array}{c}\text { Persea odoratissima (Nees) kosterm, Cinnamomum tamala } \\
\text { Nees., C. bejolghota (Buchanan-Hamilton), } \\
\text { C.glaucescens (Nees) Drury (Lauraceae) }\end{array}$ & 2.4495 \\
\hline 11 & $\begin{array}{l}\text { Blue Striped } \\
\text { Mime }\end{array}$ & Chilasa slateri (Hewitson) & $\begin{array}{l}\text { Litsea citrata Blume., L.kirgii Hk. f., } \\
\text { Cinnamomum camphora (L.) J. Presl. (Lauraceae) }\end{array}$ & 2.4495 \\
\hline 12 & Red Helen & Papilio helenus Linnaeus & $\begin{array}{c}\text { Evodia roxburghiana Benth., Glycosmis arborea(Roxb.) DC., } \\
\text { Toddalia asiatica Lamk., Zanthoxylum acanthopodium DC., } \\
\text { Z. rhetsa (Roxb.) DC. (Rutaceae) }\end{array}$ & 3.4641 \\
\hline 13 & Common Mime & Chilasa clytia (Linnaeus) & Cinnamomum camphora (L.) J. Presl., (Lauraceae) & 1.000 \\
\hline 14 & $\begin{array}{l}\text { Common } \\
\text { Mormon }\end{array}$ & Papilio polytes Linnaeus & $\begin{array}{l}\text { Aegle marmelos Correa., Citrus medica Linn., C.grandis L., } \\
\text { C.limona Osbeck, Glycosmis arborea (Roxb.) DC., } \\
\text { Murraya koenigii Spreng., Toddalia asiatica Lamk. (Rutaceae) }\end{array}$ & 3.873 \\
\hline 15 & $\begin{array}{l}\text { Common } \\
\text { Raven }\end{array}$ & Papilio castor Westwood & $\begin{array}{c}\text { Glycosmis arborea (Roxb.) DC., Toddalia asiatica Lamk. } \\
\text { (Rutaceae) }\end{array}$ & 2.4495 \\
\hline 16 & Great Mormon & Papilio memnon Linnaeus & Citrus grandis L., C.medica Linn., C.limona Osbeck (Rutaceae) & 1.4142 \\
\hline 17 & Blue Mormon & $\begin{array}{l}\text { Papilio polymnestor } \\
\text { Cramer }\end{array}$ & $\begin{array}{c}\text { Citrus grandis L., C.limona Osbeck, Glycosmis arborea (Roxb.) } \\
\text { DC., Paramignya monophylla Wright, } \\
\text { Naringi crenulata (Roxb.) Nicols. (Rutaceae) }\end{array}$ & 3.4641 \\
\hline 18 & Lime Butterfly & $\begin{array}{l}\text { Papilio demoleus } \\
\quad \text { Linnaeus }\end{array}$ & $\begin{array}{l}\text { Aegle marmelos Correa., Citrus medica Linn., C. grandis L., } \\
\text { C. limona Osbeck, Glycosmis arborea (Roxb.) DC., } \\
\text { Limonia crenulata Roxb., Murraya koenigii Spreng. (Rutaceae) }\end{array}$ & 3.873 \\
\hline 19 & Blue Peacock & $\begin{array}{l}\text { Papilio acturus } \\
\text { Westwood }\end{array}$ & $\begin{array}{c}\text { Clausena pentaphylla DC., Zanthoxylum acanthipodium DC., } \\
\text { Z.armatum DC. (Rutaceae) }\end{array}$ & 2.4495 \\
\hline 20 & $\begin{array}{l}\text { Krishna } \\
\text { Peacock }\end{array}$ & Papilio krishna Moore & $\begin{array}{c}\text { Citrus medica Linn., C. limona Osbeck, } \\
\text { Zanthoxylum acanthipodium DC. (Rutaceae) }\end{array}$ & 2.4495 \\
\hline
\end{tabular}




\begin{tabular}{|c|c|c|c|c|}
\hline \multicolumn{5}{|c|}{ Continued } \\
\hline 21 & $\begin{array}{l}\text { Common } \\
\text { Peacock }\end{array}$ & $\begin{array}{l}\text { Papilio polyctor } \\
\text { Boisduval }\end{array}$ & Zanthoxylum acanthipodium DC., Z. armatum DC. (Rutaceae) & 1.4142 \\
\hline 22 & Great Windmill & $\begin{array}{l}\text { Atrophaneura dasarada } \\
\text { (Moore) }\end{array}$ & $\begin{array}{l}\text { Aristolochia griffithi Hook. f. \& Thoms. Ex Duchartre in DC } \\
\text { (Aristolochiaceae) }\end{array}$ & 1.000 \\
\hline 23 & $\begin{array}{l}\text { Common } \\
\text { Rose }\end{array}$ & $\begin{array}{l}\text { Atrophaneura } \\
\text { aristolochiae (Fabricius) }\end{array}$ & Aristolochia tagala Cham. \&Schlect, A.indica (Aristolochiaceae) & 1.4142 \\
\hline 24 & Crimson Rose & $\begin{array}{l}\text { Atrophaneura hector } \\
\text { (Linnaeus) }\end{array}$ & Aristolochia indica (Aristolochiaceae) & 1.000 \\
\hline 25 & $\begin{array}{l}\text { Common } \\
\text { Birdwing }\end{array}$ & Troides helena (Linnaeus) & Aristolochia tagala Cham. \& Schlect, (Aristolochiaceae) & 1.000 \\
\hline 26 & Spot Swordtail & Graphium nomius (Esper) & Polyalthia longifolia Hk. f. \& T. (Annonaceae) & 1.000 \\
\hline
\end{tabular}

Table 2. Species Diversity and Species Richness values of papilionid butterflies across various altitudinal belts in the study site.

\begin{tabular}{|c|c|c|c|}
\hline $\begin{array}{l}\text { Altitudinal } \\
\text { range (masl) }\end{array}$ & Butterfly species (number of individuals) & $\begin{array}{l}\text { Shannon Diversity } \\
\text { Index }\left(\mathrm{H}^{\prime}\right)\end{array}$ & $\begin{array}{c}\text { Species } \\
\text { Richness (R) }\end{array}$ \\
\hline Upto 200 & $\begin{array}{l}\text { 3(26), 4(22), b(16), 6(12), 7(25), 8(16), 13(10), 14(29), } \\
\text { 16(12), 17(17), 18(20), 23(14), 24(13), 25(16) }\end{array}$ & 2.589 & 2.358 \\
\hline $300-500$ & 4(10), 5(9), 6(12), 7(8), 8(9), 15(10), 14(19), 16(10), 18(6), 23(9), 24(8), 25(6), 17(10) & 2.519 & 2.481 \\
\hline $600-800$ & $\begin{array}{c}\text { 3(12), 4(10), 5(7), 6(9), 7(12), 8(16), 14(21), 15(13), 16(15), 18(10), } \\
\text { 21(8), 23(9), 24(11), 25(7), 13(6), 17(8), 26(4) }\end{array}$ & 2.762 & 3.088 \\
\hline $900-1100$ & $\begin{array}{l}\text { 3(13), 4(8), 6(15), 5(19), 7(19), 8(17), 13(8), 14(22), 15(17), 16(13), 17(8), 18(14), } \\
\text { 19(7), 20(3), 21(6), 23(8), 24(10), 25(10), 12(12), 11(4), 9(6), 26(10) }\end{array}$ & 2.988 & 3.806 \\
\hline $1200-1400$ & $\begin{array}{l}\text { 3(8), 4(10), 6(6), 5(12), 7(18), 8(16), 9(4), 10(5), 11(6), 12(8), 13(12), 14(20), } \\
\text { 15(4), 16(13), 17(8), 18(10), 19(7), 20(6), 21(8), 23(10), 24(12), 22(10) }\end{array}$ & 2.999 & 3.917 \\
\hline $1500-1700$ & $\begin{array}{l}\text { 3(7), 4(10), 5(5), 7(14), 8(8), 9(5), 10(6), 11(5), 12(10), 13(8), } \\
\text { 14(17), 16(8), 17(9), 18(18), 20(5), 21(6), 22(6), 23(2), 24(2) }\end{array}$ & 2.806 & 3.588 \\
\hline $1800-2000$ & $\begin{array}{c}3(6), 4(7), 7(4), 9(5), 10(6), 11(7), 12(16), 13(8), 14(12) \\
16(3), 17(7), 18(17), 20(4), 21(6), 22(5)\end{array}$ & 2.580 & 2.962 \\
\hline $2100-2300$ & 3(5), 4(6), 9(5), 10(6), 11(5), 12(5), 13(8), 17(4), 18(4), 20(3), 21(3), 22(2), 1(5), 2(4) & 2.589 & 3.114 \\
\hline $2400-2600$ & 1(6), 2(4), 3(5), 4(5), 9(4), 10(3), 13(3), 20(2), 22(3) & 2.149 & 2.250 \\
\hline $2700-2900$ & 1(4), 2(3), 3(5), 4(3), 9(3), 20(2), 22(1) & 1.860 & 1.971 \\
\hline Above 3200 & 1(4), 2(3), 20(1) & 0.974 & 0.962 \\
\hline
\end{tabular}

${ }^{\text {a }}$ The names of butterfly species are expressed as codes (in bold) on the basis of their Sr. No. as mentioned in Table 1.

Their associations with their respective food plants justify their distribution along the entire stretch of outer Himalayas [2,16]. A wide variety of rutaceous larval host plants (notably Zanthoxylum armatum and Citrus sp.) of Papilio acturus, P. krishna, P. polyctor, P. memnon and P. polymnestor from the Eastern Himalayas, as reported by [41] are available. Occurrence of Toddalia asiatica and Paramignya crenulata as confirmed by [18] also justify their inclusion as larval host plants of Papilio castor and P. polymnestor butterflies. In the Eastern Himalayas, only Aristolochia griffithii occurs in the temperate zone above 1800 masl [42,20] and exclusively supports the larval population of Atrophaneura dasarada, Troides helena and Bhutanitis lidderdalei. Distribution of Aristolochia tagala and A. indica along lower Himalayan foothills justify the occurrence of Atrophaneura aristolochiae and Atrophaneura hector across wide altitudinal limits and Troides helena up to 900 masl [2]. Thus, association between black bodied papilionids with Rutaceae and red bodied papilionid with Aristolochiaceae 


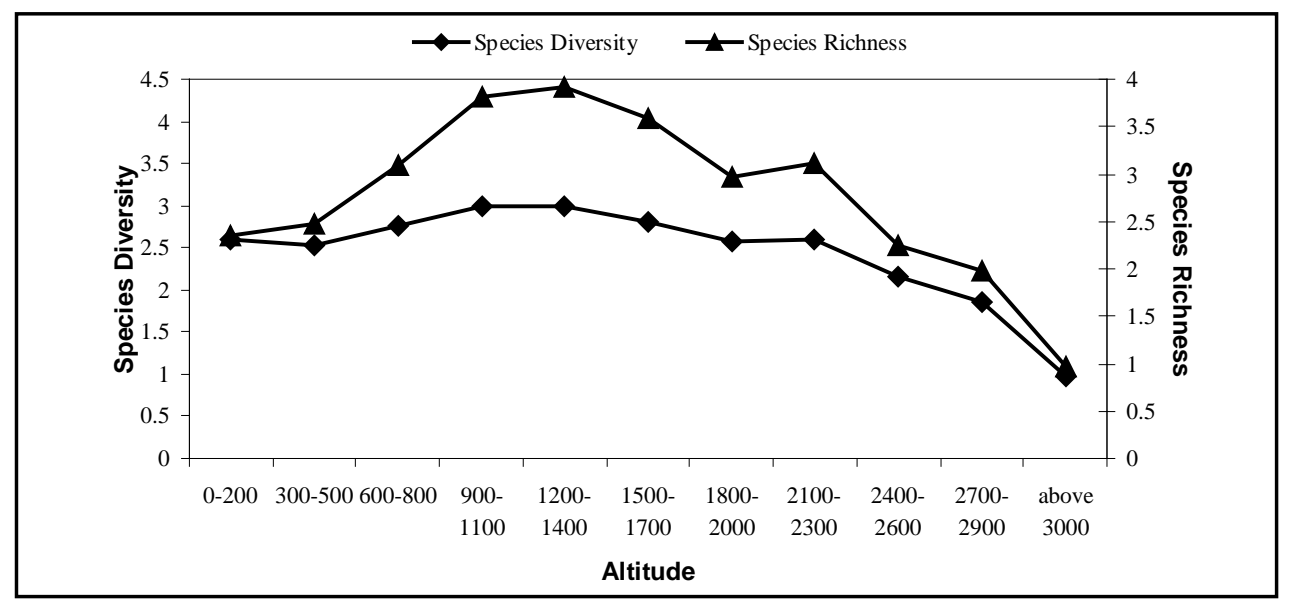

Figure 1. Variation in Species Diversity $\left(\mathrm{H}^{\prime}\right)$ and Species Richness (R) of papilionid butterflies across different altitudinal zones in the study site where altitude is expressed as masl.

were similar to observations on Assam swallowtails [43].

In case of the monophagous species, Teinopalpus imperialis the exclusive occurrence of Magnolia campbelli above 2130 masl [18] seems to be the decisive factor governing their distribution in montane habitat. Also monophagous in nature, Meandrusa payeni occurs in the Himalayan landscape due to its association with Litsea citrata [18]. While Lauraceae-Magnoliaceae served as the food resource for Graphium cloanthus [2], Chilasa agestor and C. slateri depended solely on Lauraceae to sustain their larval population [15,16].

Such narrow range of sustenance on host plants, especially the monophagous and oligophagous species of higher altitudinal zone, may serve as indicator species for future reference to environmental changes, if any.

\section{Acknowledgements}

The authors are thankful to the Head, Department of Zoology, West Bengal State University, West Bengal, India for his constant encouragement and support. Authors would also like to extend their gratitude to Professor Gour Maiti, Department of Botany, Kalyani University, West Bengal, India for his assistance in the identification of plant resources.

\section{References}

[1] Smetacek, P. (2011) On the Anomalous Altitudinal Distribution of West Himalayan Troidini and Papilionini (Papilionidae). Journal of the Lepidopterists' Society, 65, 126-132.

[2] Kehimkar, I. (2008) The Book of Indian Butterflies. Bombay Natural History Society, Oxford University Press.

[3] Joshi, P.C. and Arya, M. (2007) Butterfly Communities along Altitudinal Gradients in a Protected Forest in the Western Himalayas, India. The Natural History Journal of Chulalongkorn University, 7, 1-9.

[4] Smith, C. (1994) Butterflies of Nepal. Craftsman Press, Bangkok.

[5] Singh, A.P. (2012) Lowland Forest Butterflies of the Sankosh River Catchment, Bhutan. Journal of Threatened Taxa, 4, 3085-3102. http://dx.doi.org/10.11609/JoTT.o2625.3085-102

[6] Maude, E.W. (1949) List of Butterflies Caught in Darjeeling District between 1700 and 4400 ft. Parts I, II, III, and IV. Journal of Bengal Natural History Society, 23, 86-92.

[7] Das, R.P., Saha, G.K., De, J.K. and Sanyal, A.K. (2012) Diversity and Habitat Preferences of Butterflies in Gorumara National Park, West Bengal, India. Journal of research in Biology, 2, 303-314.

[8] MOEF (Ministry of Environment and Forests) (1990) Joint Forest Management Resolution, of Environment, Forests and Wildlife. Government of India, New Delhi, India.

[9] Kunte, K. (1997) Seasonal Patterns in Butterfly Abundance and Species Diversity in Four Tropical Habitats in Northern Western Ghats. Journal of Bioscience, 22, 593-603. http://dx.doi.org/10.1007/BF02703397

[10] Rodgers and Panwar (1988) Planning a Wildlife Protected Area Network in India. 2 vol. Project FO: IND/82/003, FAO, Dehradun, 339, 267. 
[11] Mandal, S. (2007) Wild fauna of Gorumara National Park, Jalpaiguri, West Bengal. Intas Polivet, 8, 257-261.

[12] Mallick, J.K. (2010) Status of Red Panda Ailurus fulgens in Neora Valley National Park, Darjeeling District, West Bengal, India. Small Carnivore Conservation, 43, 30-36.

[13] Pollard, E. (1977) A Method for Assessing Changes in the Abundance of Butterflies. Biological Conservation, 12, 115-134. http://dx.doi.org/10.1016/0006-3207(77)90065-9

[14] Evans, J.H. (1932) Identification of Indian Butterflies. Bombay Natural History Society, Mumbai.

[15] Wynter-Blyth, M.A. (1957) Butterflies of the Indian Region. Bombay Natural History Society.

[16] Haribal, M. (1992) The Butterflies of Sikkim Himalaya and their natural history. Sikkim. Sikkim Natural Conservation Foundation.

[17] Kunte, K. (2000) Butterflies of Peninsular India. Indian Academy of Sciences, Bangalore. University Press, Hyderabad.

[18] Cowan, A. and Cowan, J.M. (1979) The Trees of Northern Bengal Including Shrubs, Woody Climber, Bamboos, Palms and Tree Ferns. Naaz Offset Press, Delhi.

[19] Polunin, O. and Stainton, A. (2005) Flowers of the Himalaya. Seventh Impression. Oxford University Press, New Delhi.

[20] Maity, D. and Maiti, G.G. (2007) The Wild Flowers of Kanchenjunga Biosphere Reserve, Sikkim, Naya Udyog, Kolkata.

[21] Das, A.P., Bhujel, R.B. and Lama, D. (2008) Plant Resources in the Protected Areas and Proposed Corridors of Darjeeling, India, In: Chettri, N., Shakya, B. and Sharma, E., Eds., Biodiversity Conservation in the Kangchenjunga Landscape, Hill Side Press (P.) Ltd., Kathmandu, 56-79.

[22] Shannon, C.E. (1948) A mathematical Theory of Communication. Bell System Technical Journal, 27, 379-423,623656.

[23] Magurran, A.E. (1988) Ecological Diversity and Its Measurements. University Press, Cambridge. http://dx.doi.org/10.1007/978-94-015-7358-0

[24] García-Barros, E. and Fartmann, T. (2009) Butterfly Oviposition: Sites, Behaviour and Modes. In: Settele, J., Shreeve, T., Konvička, M. and Van Dyck, H., Eds., Ecology of Butterflies in Europe, Cambridge University Press, Cambridge, 29-42.

[25] Kerr, J.T. (2001) Butterfly Species Richness Patterns in Canada: Energy, Heterogeneity, and Potential Consequences of Climate Change. Conservation Ecology, 5. http://www.consecol.org/vol5/iss1/art10

[26] Kerr, J.T, Southwood, T.R.E. and Cihlar, J. (2001) Remotely Sensed Habitat Diversity Predicts Butterfly Species Richness and Community Similarity in Canada. Proceedings of the National Academy of Sciences, USA, 98, 1136511370. http://dx.doi.org/10.1073/pnas.201398398

[27] Choi, S.W. (2004) Trends in Butterfly Species Richness in Response to the Peninsular Effect in South Korea. Journal of Biogeography, 31, 587-592. http://dx.doi.org/10.1046/j.1365-2699.2003.01007.x

[28] Bhusal D.R, and Khanal, B. (2008) Seasonal and Altitudinal Variation of Butterflies in Eastern Siwalik of Nepal. Journal of Natural History Museum, 23, 82-87.

[29] Rakbek, C. (1995) The Elevational Gradient of Species Richness: A Uniform Pattern? Ecography, 18, $200-205$. http://dx.doi.org/10.1111/j.1600-0587.1995.tb00341.x

[30] Quinn, R.M., Gaston K.J. and Roy D.B. (1998) Coincidence in the Distribution of Butterflies and Their Foodplants. Ecography, 21, 279-288. http://dx.doi.org/10.1111/j.1600-0587.1998.tb00565.x

[31] Gutierrez D, and Mendez, R. (1995) Phenology of Butterflies in a Mountain Area in Northern Iberian Peninsula. Ecography, 18, 209-216. http://dx.doi.org/10.1111/j.1600-0587.1995.tb00123.x

[32] Cowley, M.J.R., Thomas, C.D., Wilson, R.J., Leon-Córtes, J.L., Gutiérrez, D. and Bulman, C.R. (2001) The Density and Distribution of British Butterflies. II. An Assessment of Mechanisms. Journal of Animal Ecology, 70, 426-441. http://dx.doi.org/10.1046/j.1365-2656.2001.00509.x

[33] Uniyal, V.P. (2007) Butterflies in the Great Himalayan Conservation Landscape in Himachal Pradesh, Western Himalaya. Entomon, 32, 119-127.

[34] Slansky, F. (1993) Nutritional Ecology: The Fundamental Quests for Nutrients. In: Stamp, N.E. and Casey, T.E., Eds., Caterpillars-Ecological and Evolutionary Constraints on Foraging, Champion and Hall, New York, 29-91.

[35] Lawton, J.H. (1983) Plant Architecture and the Diversity of Phytophagous Insects. Annual Review of Entomology, 28, 23-39. http://dx.doi.org/10.1146/annurev.en.28.010183.000323

[36] Basset, Y. (1991) The Seasonality of Arboreal Arthropods Foraging within an Australian Rainforest Tree. Ecological 
Entomology, 16, 265-278. http://dx.doi.org/10.1111/j.1365-2311.1991.tb00217.x

[37] Leather, S.R. (1990) The Analysis of Species-Area Relationships, with Particular Reference to Macrolepidoptera on Rosaceae: How Important Is Insect Data-Set Quality? Entomologist, 109, 8-16.

[38] Williams, P.H., Humphrics, C.J. and Gaston, K.J. (1994) Centres of Seed-Plant Diversity: The Family Way. Proceedings of the Royal Society of London B, 256, 67-70. http://dx.doi.org/10.1098/rspb.1994.0050

[39] Scriber, J. M., Tsubaki, Y. and Lederhouse, R.C. (1995) Swallowtail Butterflies: Their Ecology and Evolutionary Biology. Scientific Publishers, Gainesville, Florida.

[40] Barua, K.K., Slowik, J., Bobo, K.S. and Muehlenberg, M. (2010) Correlations of Rainfall and Forest Type with Papilionid Assemblages in Assam in Northeast India. Psyche, 2010, 1-10. http://dx.doi.org/10.1155/2010/560396

[41] Robinson, G.S., Ackery, P.R., Kitching, I.J., Beccaloni, G.W and Hernández, L.M. (2001) Hostplants of the Moth and Butterfly Caterpillars of the Oriental Region. Southdene Sdn Bhd and Malaysian Nature Society, Malaysia.

[42] Polunin, O. and Stainton, A. (1984) Flowers of the Himalaya. Oxford University Press, New Delhi.

[43] Barua, K.K., Kakati, D. and Kalita, J. (2004) Present Status of Swallowtail Butterflies in Garbhanga Reserve Forest, Assam, India. Zoos’Print Journal, 19, 1439-1441. http://dx.doi.org/10.11609/JoTT.ZPJ.1000.1439-41 